\begin{tabular}{|c|l|}
\hline Title & $\begin{array}{l}\text { A ssessing farmers' perspectives on climate change for effective farm-level adaptation measures in Khy ber } \\
\text { Pakhtunkhwa, Pakistan }\end{array}$ \\
\hline Author(s) & Ullah, Wahid; Nafees, Muhammad; Khurshid, Muhammad; Nihei, Takaaki \\
\hline Citation & $\begin{array}{l}\text { Environmental monitoring and assessment, 191(9), 547 } \\
\text { https://doi.org/_0.1007/310661-019-7651-5 }\end{array}$ \\
\hline Issue Date & 2019-08_07 \\
\hline Doc URL & http://hdl.handle.net/2115/79185 \\
\hline Rights & The final publication is available at link.springer.com \\
\hline Type & article (author version) \\
\hline File Information & EMAS_Final_Manuscript_.pdf \\
\hline
\end{tabular}

Instructions for use 


\section{Assessing farmers' perspectives on climate change for effective farm-level adaptation measures in Khyber Pakhtunkhwa, Pakistan}

Wahid Ullah, Muhammad Nafees, Muhammad Khurshid, Takaaki Nihei

\section{Wahid Ullah}

Faculty of Foreign Studies, Center for Pakistan Studies, Jiangxi University of Science and Technology, China. No. 86, Hongqi Avenue., Ganzhou, 341000, Jiangxi, P.R. China. Email: waheedullah@live.in

Wahid Ullah is currently working as an associate professor in Center for Pakistan Studies in the faculty of foreign studies at Jiangxi University of Science and Technology, China. Previously, he has done Ph.D. in the Department of Human Geography of Hokkaido University, Japan. He is involved in research focusing on vulnerability and adaptation of indigenous communities towards climate change induced natural disasters in Pakistan. His fields of interest are climate change, disaster risk reduction, poverty reduction and livelihood improvement through sustainable agriculture and natural resource management. Previously, he worked for the Center for International Forestry Research on identifying suitable conditions for efficient and sustainable participatory monitoring, reporting and verification systems of carbon emissions so that it can be embedded into a national database.

\section{Muhammad Nafees \\ Department of Environmental Sciences, University of Peshawar, Pakistan. Postal Code 25000. Email: nafees@upesh.edu.pk}

Muhammad Nafees has been a Professor in the Department of Environmental Sciences, the University of Peshawar since 1995. He teaches pollution control technology and environmental impact assessment (EIA) at master's and Ph.D. level. His other fields of interest are industrial pollution, solid waste management, cleaner production and freshwater resources.

\section{Muhammad Khurshid}

Department of Environmental Sciences, University of Haripur, Pakistan. Postal Code 25000. Email: khurshed75@live.com

Muhammad Khurshid has completed his PhD. in environmental sciences from the University of Peshawar, Pakistan in 2017. He previously worked with Ankara University for one year in 2016 in the department of human geography.

\section{Takaaki Nihei}

Department of Human Geography, Graduate School of Letters, Hokkaido University, Japan. Kita 10, Nishi 7, KitaKu, Sapporo, Hokkaido, JP 060-0808. Email: nihei@let.hokudai.ac.jp

Takaaki Nihei is an Associate Professor at the Department of Human Geography, Graduate School of Letters in Hokkaido University. His research specialty is agricultural and rural geography. The subject relates to food production, land use, tourism and sustainable development. He has conducted fieldwork in Japan, North America, and South America. 


\section{Author's contribution}

Takaaki Nihei supervised this research work during doctoral studies of the corresponding author. Wahid Ullah, Takaaki Nihei, Muhammad Nafees conceived and designed questionnaires for field survey; Wahid Ullah, Muhammad Nafees, and Muhammad Khurshid conducted field survey for data collection; Wahid Ullah analyzed

data; Wahid Ullah, Takkaki Nihei, Muhammad Khurshid and Muhammad Nafees contributed materials/analysis tools; Wahid Ullah, Takkaki Nihei, Muhammad Khurshid and Muhammad Nafees wrote the paper. 


\title{
Highlights
}

1. Rural farmers acknowledge changes in climate and consider it as a great threat to their livelihood but often fails to adapt timely and effectively due to economic and technological barriers they face.

2. To reduce the negative impacts of climate change, poor rural farmers usually tend to adapt measures that are economically feasible instead of environmentally feasible measures.

3. Rural farmers have no access to weather and climate related information.

4. Extension workers and farmers unions poorly operate in our study area, resulting in leaving farmers rely on their limited knowledge on how to cope with the climate change.

\begin{abstract}
Agriculture is considered as the backbone of the economy of Pakistan. However, current changes in climate have been adversely affecting agricultural productivity. In this paper, perceived impacts of climate change on agriculture and adaptation towards it have been studied in Charsadda district (lowlands) of Khyber Pakhtunkhwa province of Pakistan through extensive field surveys, involving 116 farm households. Results have revealed that climate change factors including fluctuating temperature, evidence of yearly long droughts and a steady shift in rainfall patterns have pressured the agriculture sector and livelihoods of the local peasants. The staggering floods of 2010 and 2011 in Pakistan have evidenced severe climatic changes in Pakistan. These countrywide floods have washed fertile soil in the study area that has directly contributed to losses in agricultural yield and increased vector-borne diseases in crops. The local farmers have commonly deployed adaptive measure such as crops diversification, changing fertilizer and planting shaded trees to minimize the impacts of changes in climate. However, these adjustments measures are perceived as not appropriate for improving farm yield. Therefore, the study suggests that improved understanding of the climate change impacts and knowledge on adapting adequately will lead to no-regret adaptation. It will also help protecting farmer's lives and livelihoods and will boost their resilience towards changing climatic conditions.
\end{abstract}

Keywords: Climate change adaptation, agriculture, fluctuating temperatures, rainfall shifts, Pakistan 


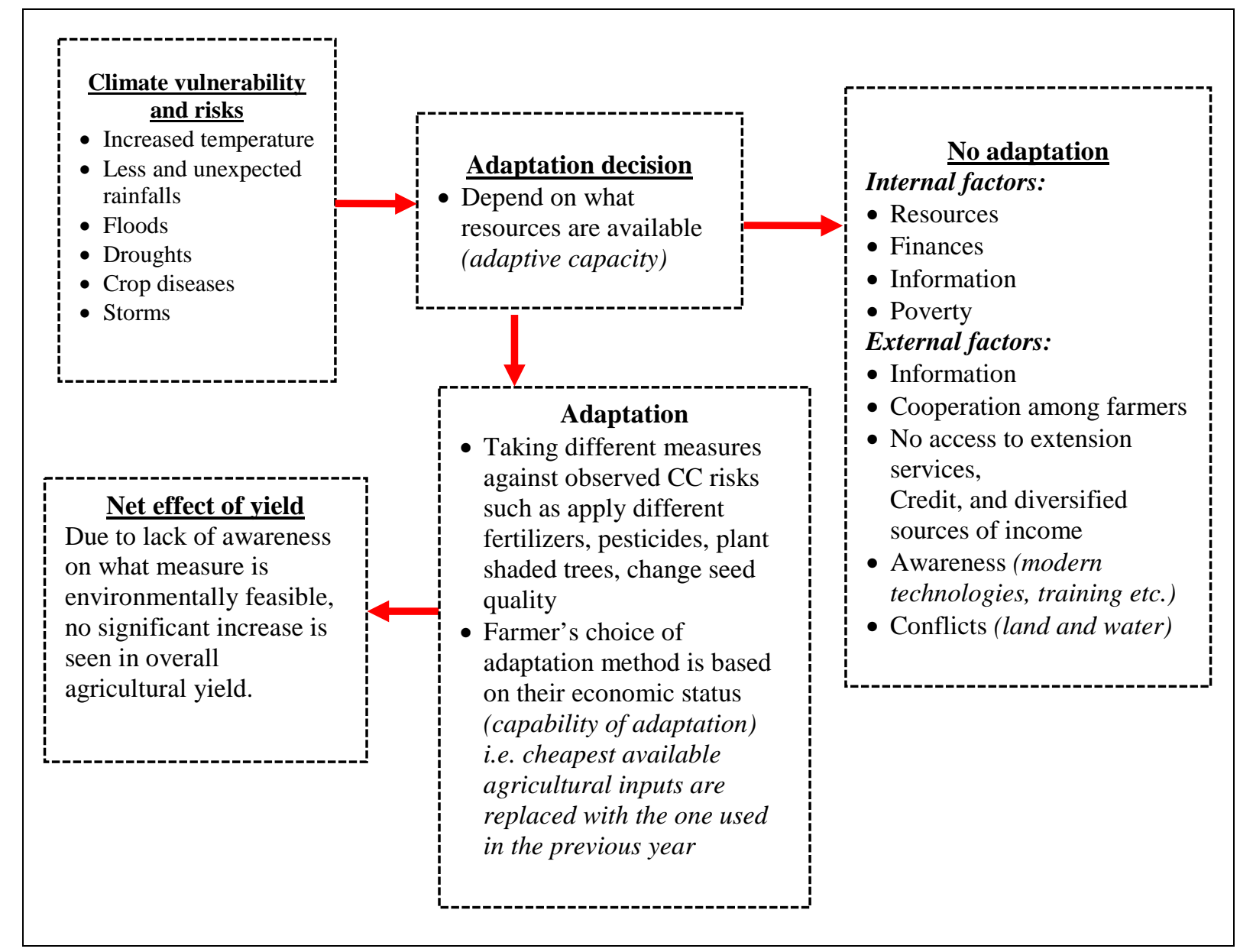

Graphical abstract of the article 


\section{Introduction}

Climate change is considered as one of the most complex challenges for societies and economies around the world. The impacts of these changes in climatic conditions varies across the world (Anita et al. 2010), where most of its severe impacts are observed in the developing countries because of numerous factors such as, poor economic conditions, lack of basic resources as well as improper utilization of available resources, weak institutional capacity and lack of knowledge and awareness regarding effective adaptive measures (Hoffman 2013). Moreover, according to International disaster database, provided by the Centre for Research on the Epidemiology of Disasters (CRED), the frequency of climate-induced disasters and hazards has also increased from the last few decades (CRED, EM-DAT 2016). Some of the prevailing impacts of climate change observed in different regions includes; fluctuating rainfall patterns, frequent floods, severe droughts, intense heat waves, melting of glaciers, and rise in sea level. (IPCC 2007; Adger et al. 2003)

Pakistan is not an exception to those disasters, in fact, it is listed in the world's highly prone regions to climate change induced natural disasters (Chaudhry 2017; Ullah et al. 2017; Javed 2016; Khan et al. 2016; MoE 2009). Particularly, these climatic changes have resulted in prolonged summer seasons and short winters in different areas of Pakistan. (Salik et al. 2015). Furthermore, the heat wave period has also increased by 31 days during the years 1980 to 2007 (Yu et al. 2013; Sultana et al. 2009). According to Chaudhry (2017), such climatic changes and its associated risks are expected to have wide-ranging impacts on every sector of life in Pakistan. For instance, the recent annual episodes of floods in Pakistan or heat waves in Karachi are the classic examples of how dangerous climate change can be for lives, livelihoods and other properties of people. Annual episodes of floods in Pakistan are due to the heavy and irregular monsoonal rains that occur mostly in July - September every year (Eid et al. 2007), resulting in substantial losses to crop yields, land, houses, and other properties, leaving majority of the locals highly vulnerable to its impacts (Atta-ur-Rahman and Khan 2013). Drylands of Pakistan are also affected by the changing climate due to a high degree of dependence on natural climatic conditions (Khan et al. 2016; Sultana and Ali 2006). Increase in temperature and reduction in rainfall has exposed farmers to great agricultural losses resulting in remarkable differences in expected crop yields (Shakoor et al. 2011; Sultana et al. 2009; Hussain and Mudasser, 2007).

High vulnerability of agriculture sector to climate change in Pakistan has pushed policy makers, researchers and development experts to revisit its policies and modify it to according to the demands of the present time. Also, it has progressively been perceived in Pakistan that agriculture sector essentially adds to the nation's GDP and play a key role in sustainable livelihoods of farmers. Notwithstanding, a few climatic elements have just been compromising the agrarian efficiency of the rural farms both monetarily and physically. These factors include; change in rainfall pattern, temperature hike, changes in sowing and harvesting period, water availability and land suitability (Sultana and Ali 2006). The farming community is often most suffered from the effects of those climatic events, causing threats not only to their farming but also reduces job opportunities in farming and investment in the agricultural sector (Sultana et al. 2009). There is no doubt that temperatures are rising and affecting farm productivity, however, helping rural farmers by providing a pathway to follow will certainly result in higher yields. In this perspective, this study is aimed to explore perceptions of farm households regarding climate change and in response adaptive measure of the 
locals towards climate change in the lowlands (i.e. District Charsadda) of Khyber Pakhtunkhwa (KP) province of Pakistan.

\section{Methods and materials}

2.1. Study area

Khyber Pakhtunkhwa (KP) is in the north-west of Pakistan and is the third largest provincial economy in the country. Agriculture is the mainstay for many inhabitants of the province. Nonetheless, not all lands are suitable for farming due to uneven topography of the area. Mostly, areas near three main rivers namely; Indus, Kabul and Swat rivers are fertile and suitable for agriculture. The Kabul River enters at a point near the south-west of the Charsadda district and is bounded by Malakand District on the north, Mardan district on the east, Nowshera and Peshawar districts on the south and Mohmand Agency on the west. District Charsadda is one of the area hit hard by floods in the province. As a result, poor rural farmers in the district areas are at substantial risk of the annual floods mainly occurs in the monsoon season i.e. July - September. Moreover, severe droughts, heavy storms are also of the greatest concern to those farmers. The study area was purposively selected as a sample site because it had previously been identified as vulnerable to the odd impacts of climate change and its induced natural disasters by many researchers like Rasul et al. (2012); Ullah et al. (2015); Saifurehman and Shaukat (2013) and Malik (2012). Natural disasters, especially floods and droughts have severely affected agriculture, lives, livelihoods and other properties of the locals in the Charsadda district (Ullah et al. 2017). For this study, two villages namely; Gulabad and Shabara were selected from Charsadda district as shown in Figure 1. 


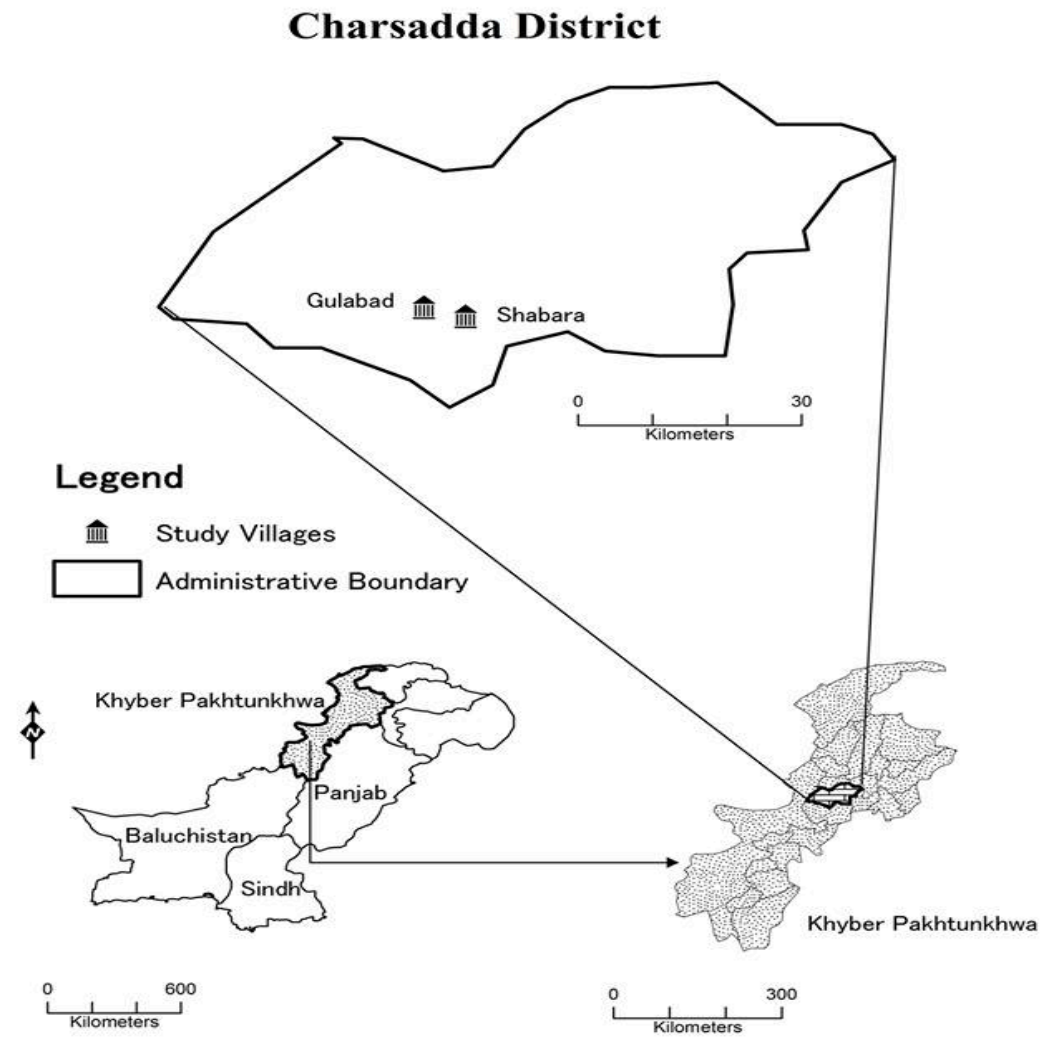

Figure 1. Map of the study area

\subsection{Sampling and data collection}

Extensive Household surveys (HHS) were carried out in two selected villages (Gulabad and Shabara) of District Charsadda. During the HHS 116 households were randomly selected for detail interviews i.e. 45 from Gulabad and 71 from Shabara. The survey mostly targeted households head using a structured questionnaire to explore research objectives. However, if they were unavailable, another adult member of the household was chosen to be interviewed. This study was performed in Pashtun tribe of Pakistan where both men and women do not mix. Therefore, the study did not include Therefore, the study did not include responses from females, due to ethic reasonings including; culture and religion. The sampled households were selected through multi-stage stratified sampling. In the first stage purposively KP was selected among the four provinces of Pakistan. In the second stage, among 24 flood-hit districts, Charasadda was purposively selected. In the third stage, the affected area was divided into two categories of urban and rural areas. The urban territory was barred from the review as per the objectives of the study i.e. only farmer's risk management strategies to be studied and farming is not practiced in urban areas. Later, in the last stage, 116 respondents were randomly selected (simeple random sampling) from the total population of two villages in the district 
keeping in view the homogeneity and heterogeneity such as climatic conditions, farming practices, irrigation facilities and distance from the river. The sample size was relatively smaller due to budget constraints.

Two field assistants participated in the research in order to help the author of this paper to collect primary data from the study area. A one-day intensive workshop was arranged to train field assistants prior to visit stud villages. The study team administered all questionnaires personally. Before starting the HHS, purpose, and objective of this study were clearly explained. Afterward, respondents were asked for an informal verbal consent. Generally, the household survey lasted for approximately an hour. The survey was conducted in September and October 2016. The survey includes questions on awareness among villagers regarding climate change and its key factors affecting agricultural production, locally perceived best and worst years for agricultural production, and damages associated climate change induced natural disasters. Adaptation techniques employed to reduce the negative impacts of climate change were also part of the survey.

\section{Results and discussion}

This section of the research starts with describing farmer's perception and awareness towards climate change. Then the paper reports perceptions of surveyed respondents on the most prevalent natural disasters in the study area, a brief history of agricultural production (best suitable and perceived worst year), and damages caused by climateinduced natural disasters. The analysis then moves to identify the key factors of climate change affecting farming and then explore adaptation practices deployed to reduce the negative impacts of climate change on agriculture in the study area. Investigation on how education and farm experience influence decisions on changes in adaptation measures are also part of the analysis which is followed by the conclusion of this paper in the last section.

\subsection{Farmer's awareness and perception of key factors of climate change}

Climate change is perceived differently due to its impacts beings distinctive across the study area. It is crucial to know how farmers perceive climate change to be able to design effective policies for supporting sustainable agriculture. Survey results presented in Table 1 revealed that $87 \%$ and $92 \%$ of the respondents understood climate change (changes in the short and long-term weather) in Gulabad and Shabara respectively. Most of the sampled households in Gulabad heard of climate change either from village elders (42\%) or through electronic media mainly through radio (36\%) while in Shabara, village elders were the main source of information on climate change (83\%). Village elders share their experiences with other farmers and discuss how environmental situations have changed over time. Moreover, 33\% of the respondents in Gulabad and 68\% in Shabara perceived that the common factors changed due to climate change includes an increase in temperature and unpredicted rain falls (54\% in Gulabad and 36\% in Shabara). Changes in these conditions have made cultivating troublesome and have likewise essentially decreased agricultural production in the studied territory. Few numbers of households perceived an increase in the frequency of extreme events such as floods, droughts etc. but they reported that natural hazards especially floods have also become more disastrous in recent past years. 
Table 1. Agricultural seasonal calendar of Charsadda district

\begin{tabular}{|c|c|c|c|c|c|c|c|c|c|c|c|c|c|c|}
\hline & $\mathbf{W}$ & $\mathbf{M}$ & & & & & & & & & & & & \\
\hline Months & & "ा & 1 & 2 & 3 & 4 & 5 & 6 & 7 & 8 & 9 & 10 & 11 & 12 \\
\hline Agricultural Activities & & & & & & & & & & & & & & \\
\hline Wheat & & & & & & & & & & & & & & \\
\hline Sugar Cane & & & & & & & & & & & & & & \\
\hline $\begin{array}{l}\text { Eucalyptus (harvest every } \\
4 \text { to } 5 \text { years) }\end{array}$ & & & & & & & & & & & & & & \\
\hline Maize & & & & & & & & & & & & & & \\
\hline Tomato & & & & & & & & & & & & & & \\
\hline Potato (summer crop) & & & & & & & & & & & & & & \\
\hline Potato (Winter crop) & & & & & & & & & & & & & & \\
\hline Onion (summer crop) & & & & & & & & & & & & & & \\
\hline Onion (Winter crop) & & & & & & & & & & & & & & \\
\hline Okra & & & & & & & & & & & & & & \\
\hline Cucumber & & & & & & & & & & & & & & \\
\hline Chilli & & & & & & & & & & & & & & \\
\hline Bottle Gourd & & & & & & & & & & & & & & \\
\hline Bitter Gourd & & & & & & & & & & & & & & \\
\hline Brinjal & & & & & & & & & & & & & & \\
\hline Peas & & & & & & & & & & & & & & \\
\hline Disasters & & & & & & & & & & & & & & \\
\hline Flood/ Heavy Rainfall & & & & & & & & & & & & & & \\
\hline Storms & & & & & & & & & & & & & & \\
\hline $\begin{array}{l}\text { Droughts (doesn't happen } \\
\text { every year) }\end{array}$ & & & & & & & & & & & & & & \\
\hline Planting & $c^{-}$ & & & & & & & & & ng & b & & & \\
\hline
\end{tabular}

Note: $W$ stands for women and $M$ for men whereas the Arabic numerals in the second row are used for showing names of months such as 1 for January; 2 for February and so on.

Previous studies of literature have shown that if farmers are aware of the changes occurring in the climate, or to the risks associated with it, they can take precautions and better prepare for it (Qasim et al. 2015). The population that are highly exposed to those risks are obliged to take actions against it to minimize its devastating impacts. In this study, most of the farmers acknowledged changes in climate and perceived that the increasing temperature, extreme drought situation and changing rainfall pattern are among the major threats to farming in the study area. Similar findings have been reported by Khan et al. (2016); Abid et al. (2015 and 2016) by mentioning that climate-induced disasters especially floods have become more disastrous in recent past years. Besides, the outcomes of this study are additionally in accordance with the information appeared by the Center for Research on the Epidemiology of Disasters (CRED - 
EM-DAT) for Pakistan. Other studies conducted in the region have also demonstrated that this increase in the frequency of natural disasters can be linked to climate change (Atta-ur-Rehman and Khan 2013; Epkoh 2010; Adger et al., 2003; and MoE 2009). The consequences of such changes have been devastating for the lives and livelihoods of poor rural farmers. Researchers from Pakistan have reported that the absence of early warning systems in disaster-prone areas like Charsadda exposes communities to negative impacts of climate change. Although, institutions like Pakistan Metrological Department and National and Provincial Disaster Management Authorities regularly update their websites by posting daily weather reports and other relevant information that can be helpful for rural farmers, but their ignorance towards using modern technologies, and using internet makes the information less significant in protecting farmers from the negative impacts of climate change. Rather, agriculturists in the surveyed area generally depended on customary learning of town seniors (associated with cultivating) regarding what transformations they have seen in short and long-term climate.

\subsection{Farmers` perceptions about climate change risks}

In Pakistan, many rural populations have still been vigorously reliant on agriculture for their livelihood. Despite the constrained access to farm assists and resources like compost, pesticides, decent quality seed, water for irrigation, labor, land, and infrastructure, there are other environmental factors as well making peasants more vulnerable to climate change. Results elaborated perceptions of sampled respondents on primary risks to their agricultural production. In both villages, $70-71 \%$ of the respondents reported that weather is a primary production risk as shown in Table 2. In Shabara $59 \%$ and $44 \%$ of the respondents viewed crop pests and lack of access inputs as major perceived threats to agricultural production respectively. Participants of the survey believed that risks associated with changes in climatic conditions in the region will not only decrease their incomes from farming (view of 33 and $35 \%$ of farmers in Gulabad and Shabara respectively) but will also expose them to other threats such as floods, droughts, and storms. The fear of exposure to other threats might be due to the already observed devastating impacts and damages caused by phenomenon associated with climate change. Project on adaptation was viewed as a source of access to loans, help to improve soil fertility, provide good-quality agricultural inputs, compensate them in case of losses from disasters especially floods and more importantly help in reducing threats from climate change. In Shabara village, although a canal has been built for irrigating farming lands, but the absence of water channels makes it useless for time being. As a result, they depended purely on, on tube wells or waited for the onset of rainfall to irrigate lands. While in Gulabad, all household has access to river water for irrigation. Furthermore, respondents also hope that the project on adaptation will provide access to water for irrigation. Their responses might be helpful for agriculture and climate change policymakers to effectively make amendments in agricultural and climate change policy with an aim to make it more relevant to actual farm conditions. In addition, respondents were asked if they have any hopes from changes in climatic conditions occurring in their areas. Interestingly there were no hopes reported in both villages as in most cases, recent changes in temperature and precipitation have resulted in reducing locals agricultural yield. 
Table 2. Perception about key factors of climate change among sampled respondents in Gulabad and Shabara

\begin{tabular}{|c|c|c|c|}
\hline Indicator & Response & Gulabad (\%) & Shabara (\%) \\
\hline Do you know & Yes & 87 & 92 \\
\hline climate change? & No & 13 & 8 \\
\hline Source of & Personal & & \\
\hline Information on & observation & 7 & 4 \\
\hline climate change & Village elders & 42 & 83 \\
\hline \multirow{6}{*}{$\begin{array}{l}\text { Factor of climate } \\
\text { change that has } \\
\text { changed }\end{array}$} & Media & 36 & 11 \\
\hline & Do not know & 15 & 4 \\
\hline & $\begin{array}{l}\text { Temperature } \\
\text { change }\end{array}$ & 33 & 68 \\
\hline & $\begin{array}{l}\text { Rainfall pattern } \\
\text { change }\end{array}$ & 56 & 34 \\
\hline & $\begin{array}{l}\text { Frequency of } \\
\text { extreme events } \\
\text { has changed }\end{array}$ & 16 & 7 \\
\hline & Others & 4 & 4 \\
\hline
\end{tabular}

3.3. Farmer's perceptions of the most prevalent natural disasters affecting agriculture

Climate-induced natural disasters have been considered as one of the greatest threat to farming globally as well as in Pakistan. Results show that, in Gulabad, 93\% of the sampled respondents conceived floods and 56\% conceived storms as the major consequence of climate change affecting farming (Figure 2). In Shabara, floods and droughts are the prime natural calamities that cause damages to agriculture productivity as reported by $62 \%$ and $77 \%$ of the respondents respectively. Unlike Shabara, in Gulabad, easy access to river water for irrigation was the main reason why drought did not affect farming. Crop diseases due to changing climate and variability was listed as less prevalent cause of damaging crops by most of the respondents in Gulabad. The interviewed respondents further emphasized the lack of availability of assists among poor rural farmers which exposes them to the devastating negative impacts of climate change.

Farmers are particularly more vulnerable to the floods and droughts due to their poor economic situation and low adaptive capacity towards climate change and its associated risks (Ali and Erenstein 2017; Rasul et al. 2012). These results are also in line with other studies performed across the globe (though in different geographic settings), such as a study performed by Arbuckle et al. (2014), Deressa et al. (2009), and Kurukulasuriya and Rosenthal (2003). For instance, Deressa et al. (2009) found that in Ethiopia, farmers are mainly faced with the consequences of climate change in the shape of changing rainfall patterns, severe droughts, and higher temperatures. 


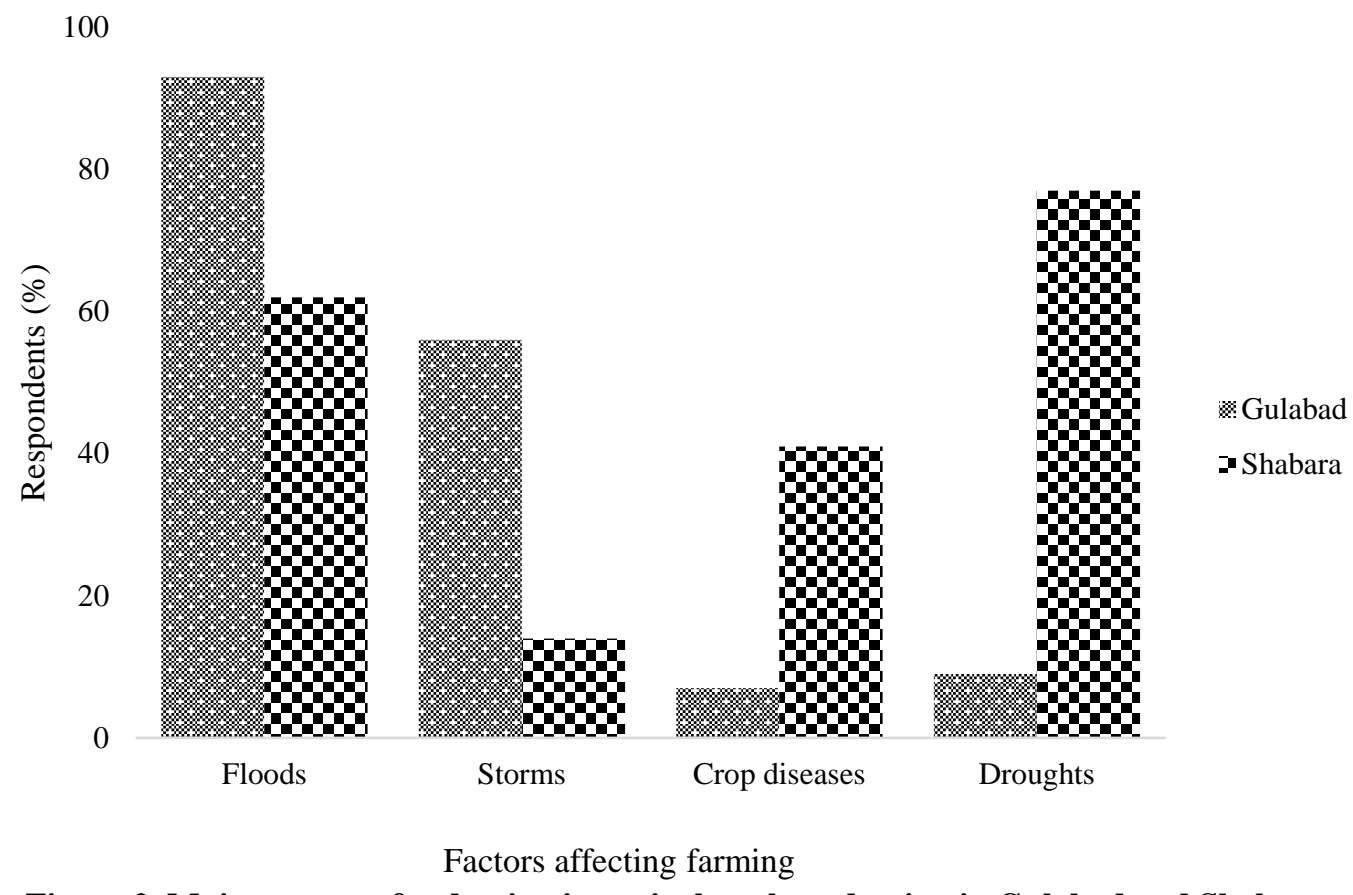

Figure 2. Major causes of reduction in agricultural production in Gulabad and Shabara

3.4. Perceptions about historical overview of production

During this study, farmers were asked to identify most suitabl, and negatively impacted years of production based on their perceptions in recent past. Interestingly, respondents could make a clear distinction of the flood year i.e. 2010, to mark most suitable and worst years for their agricultural production. In July 2010, all Pakistan in general and KP province in particular, was hit hard by a countrywide deadliest flood. Charsadda was among other 25 districts extraordinarily influenced by this flood. It is critical to refer to here that the appropriate responses given to the subject of best and most exceedingly awful year of production were completely based on respondents' memory. Analysis performed for this study show that $51 \%$ and $70 \%$ of respondents in Gulabad and Shabara perceived both the best and worst years for production after the flood year of 2010. In addition, sampled respondents reported that in the year 2011, they received the highest yield probably due to the fertile silt brought by flood water with it. This fact was noted by Atta-ur-Rehman and Khan (2013) in their study performed in Charsadda district. All standing crops and majority of the land were flooded the countrywide flood in the year 2010. Hence, majority of the respondents perceived it as the worst year for agricultural production. Besides that, most of the respondents believe that since 2011, crop yield is continuously decreasing year by year primarily due to annual episodes of floods, yearly long dry situation, soil infertility, and unpredicted rain falls or even no rainfall except that of the monsoon season.

Previous literature consistently focussed on the importance of understanding local knowledge in decisionmaking regarding climate change associated risks (Harmeling 2012; Roncoli et al. 2012). Farmers base their decision to adapt their farming practices to several other climate factors observed through personal experience such as extreme events; rainfall frequency, timing, and intensity; and early or late frosts (Deressa et al. 2009). It is evident that in some 
cases, scientific climate knowledge is solely based on local knowledge developed from everyday encounters with weather both felt and observed (Arbuckle et al. 2014). Further, how farmers comprehend and see climate-related dangers and uncertainties are critical in distinguishing legitimate management practices and adaptation mechanisms as reported by Abid et al. (2015). Lebel et al. (2015) and Ullah et al. (2015) further argues that the assessment of farmers' perceptions of climate-related risks is important because it can help understand the decision-making attitude of farmers while facing uncertain climatic conditions. Another study conducted by Sultana et al. (2009) in the Punjab province of Pakistan shows that how wheat production has been affected by the changing climatic conditions, testing food security situation in the country. Additionally, perceptions of farmers can help them make precise decisions about what crops to grow, when and with which inputs (Lucas and Pabuayon 2011) (figure 3).

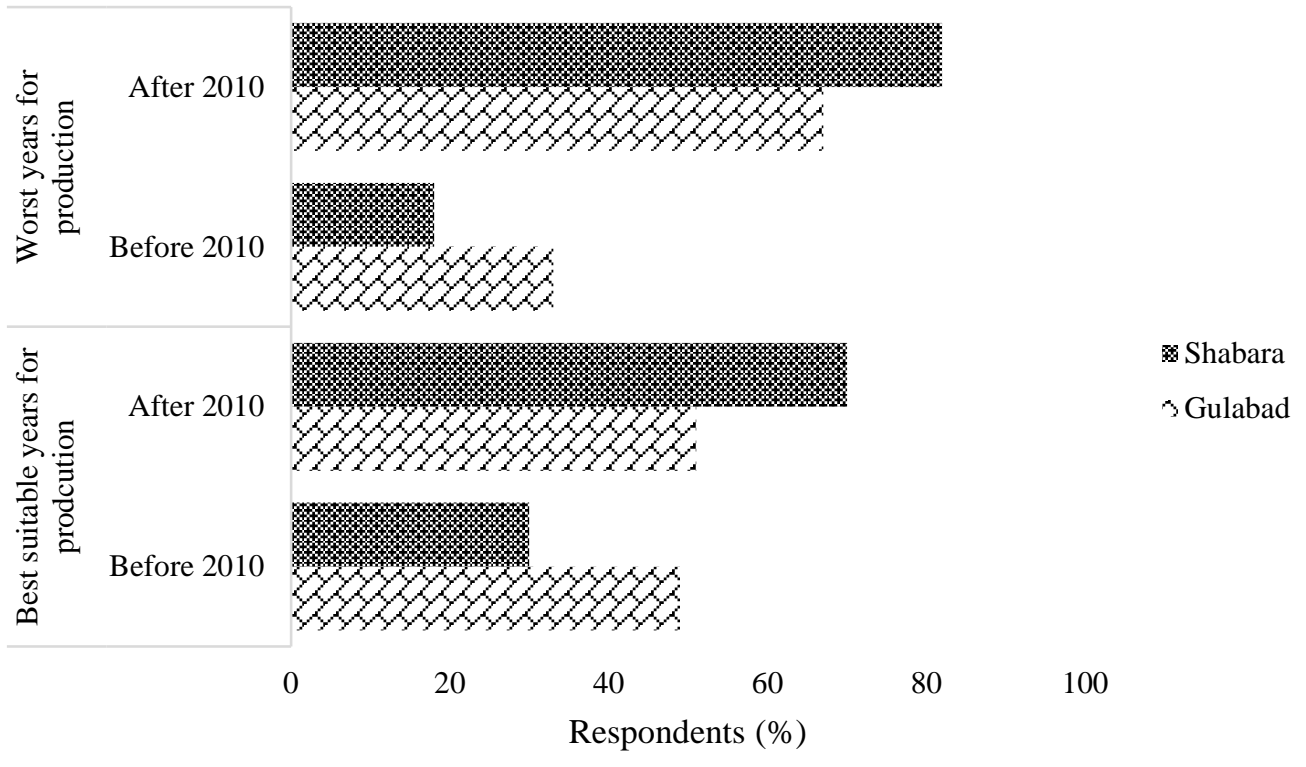

Figure 3. Perception of farmers on best suitable and worst year for agricultural production in Gulabad and Shabara

3.5. Damages occurred due to the 2010 flood in the selected villages of Charsadda District

Results from our study reveal that in both villages, more than $70 \%$ of sampled respondents have lost both land and crops due to the floods in 2010, whereas, almost 2 hectares of land was flooded costing approximately less than 300,000 PKR in Gulabad and slightly more than 200,000 PKR in Shabara. Majority of the respondents in Shabara (69\%), have lost livestock while a fewer number of households (31\%) have lost livestock in Gulabad.

For the most part, locals keep goats, cows, and buffaloes in houses. Almost all households interviewed during the surveys had lost their lands and crops. On average, standing crops of on 3.80ha of land in Shabara and 2ha in Gulabad were flooded in the year 2010. The estimated average cost of livestock loss was in the range of 154,643 to 206,122 PKR. Regarding house damage, 56-58\% of the household reported that their houses were fully damaged due to flood. Although, some support was given by government and non-governmental organizations, however, majority 
of the household i.e. 65-71\%, rebuilt it by themselves using their own resources. The estimated average cost of damage was approximately 332,742 PKR in Gulabad and 286,222 PKR in Shabara. These results depict that the damages were huge keeping in mind the financial situation of those farming communities. Unfortunately, not all of them were able to access governmental agencies for support. Hence there is a clear of coordination between locals and Governmental agencies. It is strongly advised to create networks that can help rural farmers in accessing relevant stakeholders during the time of hardship (Table 3).

Table 3. Perceived risks, and hopes from climate change among farm households in the study area

\begin{tabular}{|c|c|c|c|}
\hline & Indicators & Gulabad (\%) & $\begin{array}{l}\text { Shabara } \\
(\%)\end{array}$ \\
\hline \multirow[t]{3}{*}{ Primary production risks } & Weather & 71 & 70 \\
\hline & Crop pests & 18 & 59 \\
\hline & Lack of access to inputs & 20 & 44 \\
\hline \multirow{7}{*}{$\begin{array}{l}\text { Climate change and its } \\
\text { associated risks }\end{array}$} & No worry & 0 & 1 \\
\hline & Decrease income & 33 & 35 \\
\hline & Not compensate if losses & 20 & 6 \\
\hline & Not provide alternative income & 0 & 13 \\
\hline & Not reduce threats & 42 & 25 \\
\hline & Not provide water for irrigation & 0 & 14 \\
\hline & Others & 7 & 0 \\
\hline \multirow{6}{*}{$\begin{array}{l}\text { Hopes from adaptation } \\
\text { project }\end{array}$} & No hopes & 4 & 0 \\
\hline & Improve income form agriculture & 29 & 39 \\
\hline & Compensate if losses & 31 & 6 \\
\hline & Provide alternative income & 0 & 3 \\
\hline & Provide water for irrigation & 7 & 42 \\
\hline & Reduce threats from climate change & 31 & 11 \\
\hline \multirow{6}{*}{$\begin{array}{l}\text { Hopes from climate } \\
\text { change }\end{array}$} & No hopes & 76 & 82 \\
\hline & Improve income & 4 & 3 \\
\hline & Compensate if losses & 9 & 1 \\
\hline & Provide alternative income & 2 & 3 \\
\hline & Reduce threats from climate change & 4 & 6 \\
\hline & Others & 7 & 6 \\
\hline
\end{tabular}

3.6. Perceptions on impacts of climate change on agriculture in the study area

Figure 4 and 5 summarizes the rating of the main consequences of climate change and its effect on farming within the study area. These perceptions were measured on a four-point scale i.e. no extent, little extent, some extent, and great extent. A total of 19 indicators of climate change were pre-identified from the literature that could potentially affect agriculture, of which seven were perceived as having no to minor impact on farming and were excluded from analysis. These seven indicators include; deforestation, long duration of winter, lack of vegetation/pasture, postharvest losses, and shortening of the crop life cycle. Results indicated that $60 \%$ of the sampled respondents in Gulabad and $54 \%$ in Shabara conceived annual episodes of severe floods as a major threat to farming. Among other variables 
listed as having a higher impact on agriculture in both villages includes; loss of farmland due to floods i.e. 53\% in Gulabad and 68\% of respondents in Shabara. In Shabara, 63\% and 42\% of all the sampled respondents perceived drought and shifts in the pattern of temperature and rainfall respectively, as major contributing factors to the negative impacts of climate change on agriculture in the region. Results also revealed that decrease in soil fertility (36\% and 63\%) and high-temperature (40\% and 52\% in Gulabad and Shabara) respectively contribute to some extent to disturb farming in the study area. Whilst, other indicators included in the analysis such as long duration of winter, lack of vegetation, post-harvest losses, shortening of crops life cycle etc. were conceived as having little to no impact on farming the study area. Although, both villages are closely located to the river, but only farmers in Gulabad uses river water for irrigation. As explained earlier (section 3.2), due to the absence of water channels from the canal to farming lands, majority of the respondents in Shabara rely either on Tube-wells or rain-fed irrigation. In Shabara, among all, $44 \%$ of the respondents reported that availability of water for irrigation is one of their major concern in getting the desired yield.

100

80

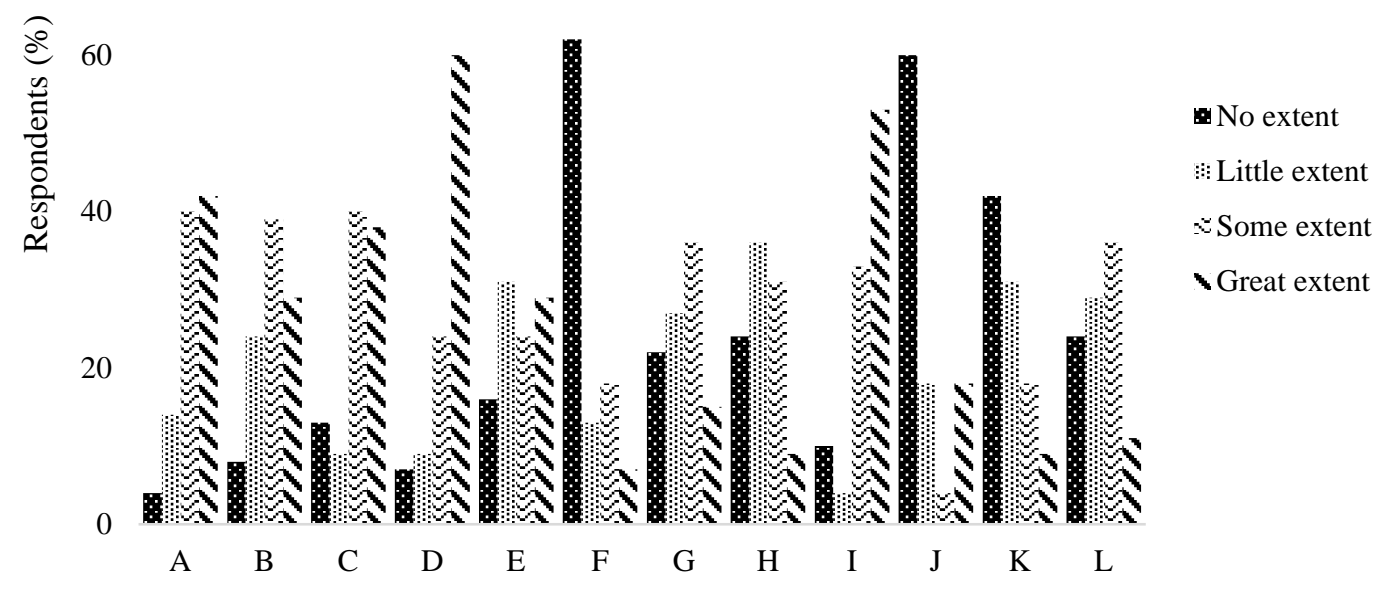

Climate change indicators in Gulabad

Figure 4. Rating impacts of climate change on agriculture in Gulabad

Note: A: High-temperature; B: High rate of precipitation; C: Pattern of rainfall and temperature; D: Floods; E: Attack of pests and diseases; F: Lack of water supply; G: Decrease in soil fertility; H: Droughts; I: Loss of farmland due to floods; J: Soil erosion; K: Long duration of summer; L: Crop destruction by high speed wind 


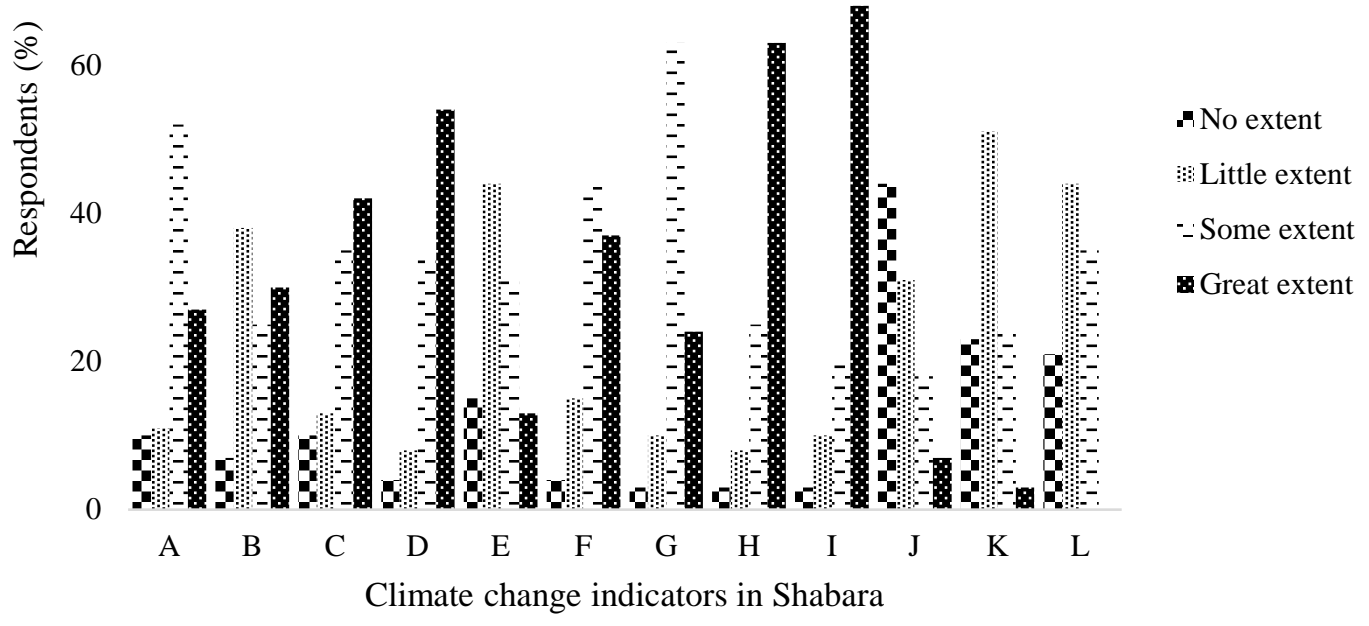

Figure 5. Rating impacts of climate change on agriculture in Shabara

Note: A: High-temperature; B: High rate of precipitation; C: Pattern of rainfall and temperature; D: Floods; E: Attack of pests and diseases; F: Lack of water supply; G: Decrease in soil fertility; H: Droughts; I: Loss of farmland due to floods; J: Soil erosion; K: Long duration of summer; L: Crop destruction by high speed wind

In different regions of Pakistan, for the most part, farmers' perceptions of climate change and experience of extreme events appear to be in line with actual climate data and matches closely with the results drawn from scientists' data analysis. Results from other studies have revealed that the steady increase in mean maximum temperature, unpredicted rain falls, a decrease in precipitation on most of part of Pakistan has resulted in agricultural losses and increasing risks of crop pests and disease outbreaks (Sultana and Ali 2006; Abbas 2009; Farooqi et al. 2005). In our case, majority of the farmers understood climate change and the major perceived consequences identified were increased in the length of summer and increase in the temperature, unpredicted rainfall, disastrous floods, severe droughts, and storms. All these factors have resulted in great agricultural losses which were observed as the only major livelihood for subsistence. Like our findings, studies performed in other parts of the country showed that floods and droughts were also the major consequences of climate change (Sultana et al. 2009; Abid et al. 2016). For instance, monsoon floods in 2010, 2011, and 2014 caused huge damages to agriculture crops, livestock, and primary infrastructures like water channels, tube wells, houses, seed stocks, fertilizers and agricultural equipment (Atta-urRehman and Khan 2013). 
Table 4. History of natural disasters caused by climate change during 1990 and 2016 in Pakistan

\begin{tabular}{|c|c|c|c|c|c|c|c|}
\hline Disaster Type & Occurrence & $\begin{array}{l}\text { Total } \\
\text { deaths } \\
\text { (persons) }\end{array}$ & $\begin{array}{l}\text { Injured } \\
\text { (persons) }\end{array}$ & $\begin{array}{l}\text { Affected } \\
\text { (persons) }\end{array}$ & $\begin{array}{l}\text { Homeless } \\
\text { (persons) }\end{array}$ & $\begin{array}{l}\text { Total } \\
\text { affected } \\
\text { (persons) }\end{array}$ & $\begin{array}{l}\text { Total } \\
\text { damage } \\
(000 \$)\end{array}$ \\
\hline Avalanche & 9 & 415 & 89 & 3833 & 300 & 4222 & \\
\hline Diseases & 6 & 126 & 111 & 14954 & 1000 & 16065 & \\
\hline Cold wave & 3 & 18 & & & & & \\
\hline Convective storm & 6 & 90 & & 500 & 594 & & \\
\hline Drought & 1 & 143 & & 2200000 & & 2200000 & 247000 \\
\hline Floods & 68 & 10165 & 10874 & 61155341 & 2980815 & 64147030 & 19799378 \\
\hline Heat wave & 11 & 2561 & 324 & 80250 & & 80574 & 18000 \\
\hline Landslide & 20 & 1523 & 301 & 1995988 & 225090 & 2221379 & 1728936 \\
\hline
\end{tabular}

Source: Autor's own calculation. Data borrowed from Centre for Research on the Epidemiology of Disasters (CRED), EM DAT, 2016. Note: empty spaces in the table shows no data available

\subsection{Adaptation strategies and source of climate-related risk}

A total of 15 adaptation strategies were identified within the study area, practiced by the sampled respondents' due to the consequences of changing climatic conditions. All the adaptations were based on local knowledge. Local people were mostly dependent on farming primarily and are facing poor economic condition. The study area is amongst the highly-exposed districts of the country. Hence, adaptation agriculture to the vagaries of climate change is considered as the most appropriate method to reduce the negative impacts of climate change. Descriptive statistics (percentage values) of respondents who were practicing a mix of adaptation strategies to adapt the climate change induced natural disasters are given in Table 6.

During the field visit, it was found that amongst all listed adaptation methods, farmers in both villages were using a mix of strategies to cope with the vagaries of climate change. The most prominent and widely used methods in both villages include; changing crop type, changing seed quality, change fertilizer, plant shaded trees and stop cutting trees due to the increased threats from floods, droughts, soil erosion and pest attacks on crops. The underlying reasons for adaptation towards climatic changes were mostly similar in both villages. Few sampled respondents deploy adaptation methods like change crop type, variety or change planting dates to ensure the desired production while facing changing climate. Due to loss of fertile soil layer by a countrywide flood occurred in the year 2010, $80 \%$ of the respondents in Gulabad and 55\% in Shabara reported that they apply more fertilizers to balance nutrients in the soil and increase crop productivity. More than half of the respondents in Gulabad and approximately 61\% in Shabara have started planting Eucalyptus around lands near the river to reduce soil erosion from floods in the monsoon season i.e. July to September. Although sampled respondents understand the importance of water for agriculture, none of them 
store water to help them during drought situation. In Gulabad, availability of water for irrigation is considered as a less prominent issue because of having good access to river water. In Shabara, although canal has been built, however, due to unavailability of water channels to lands, farmers cannot get benefit from it. Due to this situation, farmers in Shabara, mostly rely on tube-well irrigation or wait for the onset of rainfall. Pakistan is currently facing a serious electricity shortage. Hence, farmers rely on buying diesel to run tube-wells for irrigating agricultural lands. Moreover, sampled farmers mentioned that unaffordable prices of diesel make farming more expensive and unaffordable for them. To reduce high expenses of using diesel, farmers usually reduces the frequency of irrigating the land. This situation resulted in compromising on receiving lower yields due to untimely irrigation.

In the study area, most of the sampled respondents were exclusively farmers. Hence, other alternative livelihood options were not largely adopted by them particularly in Shabara. This is partly because of the inherited farming as an occupation and because of not knowing what else to do. Due to lack of access to good agricultural inputs, higher threats from annual episodes of floods, long dry conditions, and infertile soils, a few farmers tend to rent out more land for farming. Similar environmental situation exists in the neighboring districts or even worse, hence not many farmers tend to migrate to other areas, instead stay in Gulabad and Shabara. It should be noted that all these strategies, however, are mostly followed in combination with other strategies and not alone. Sampled respondents were also asked about the source of risk due to which they need to adapt to the vagaries of climate change. Prevalent annual floods, extreme droughts, soil infertility, increased crop diseases, and water scarcity were listed as the most important consequences of climate change in the study region (Table 5 and 6).

Table 5. Damage to properties (land, livestock and houses) due to 2010 floods and storms in selected villages of Charsadda district

\begin{tabular}{llll}
\hline Types of properties & Responses & \multicolumn{2}{l}{ Village Name } \\
\hline \multirow{3}{*}{ Damage to land } & & Gulabad (\%) & Shabara (\%) \\
\cline { 2 - 3 } & No damage & 29 & 24 \\
& Only crops damaged & 0 & 1 \\
& Both land and crops damaged & 71 & 75 \\
& Average land size damaged (Ha) & 1.84 & 1.95 \\
& Estimated average cost of loss (PKR) & 288,846 & 216145 \\
& & & \\
& No loss & 69 & 31 \\
& Lost livestock & 31 & 69 \\
& Average number of livestock loss per & 3.80 \\
& household & 2 & \\
& Estimated average cost of loss (PKR) & 154643 & 206122 \\
& & & 14 \\
& No damage & 20 & 28 \\
& Partially damage & 24 & 58 \\
& Full damage & 56 & 35 \\
& NGO, rebuild it & 29 & 65 \\
& Self-build & 71 & 286,222 \\
\hline
\end{tabular}


Table 6. Types of adaptation methods employed to manage negative impacts of climate change on agriculture identified by farm households

\begin{tabular}{|c|c|c|c|}
\hline \multirow[t]{2}{*}{ Adaptation strategies } & \multicolumn{2}{|c|}{ Village Name } & \multirow[t]{2}{*}{ Source of risk } \\
\hline & $\begin{array}{l}\text { Gulabad } \\
\text { (\%) }\end{array}$ & $\begin{array}{l}\text { Shabara } \\
\text { (\%) }\end{array}$ & \\
\hline \multicolumn{4}{|l|}{ Changing cropping practices } \\
\hline Change crop type & 13 & 41 & Flood, Drought \\
\hline Change crop variety & 33 & 2 & $\begin{array}{l}\text { Flood, Drought, Soil } \\
\text { fertility, maximum } \\
\text { extreme temperature }\end{array}$ \\
\hline Change planting dates/season & -- & 7 & Flood, Drought \\
\hline \multicolumn{4}{|c|}{ Change farm management techniques } \\
\hline Change fertilizer & 82 & 55 & $\begin{array}{l}\text { Drought, Soil fertility, } \\
\text { crop pests }\end{array}$ \\
\hline Change pesticide & 36 & 18 & Drought, Crop pests \\
\hline Change irrigation & 4 & 17 & Drought, soil problems \\
\hline Change seed quality & 58 & 79 & Drought, Crop pests \\
\hline \multicolumn{4}{|c|}{ Advance land use management measures } \\
\hline Plant shaded trees & 58 & 61 & Flood, Soil erosion \\
\hline Stop cutting trees & 16 & 13 & Flood, Soil erosion \\
\hline Store water & 2 & 3 & Drought, Water scarcity \\
\hline Farm diversification & 24 & 11 & Soil fertility, Drought \\
\hline $\begin{array}{l}\text { Change farm management } \\
\text { techniques }\end{array}$ & 7 & -- & $\begin{array}{l}\text { Flood, Crop pests, } \\
\text { Drought }\end{array}$ \\
\hline \multicolumn{4}{|l|}{ Livelihood options } \\
\hline Shift from crop to livestock & 9 & -- & Flood, Drought \\
\hline Migration & 9 & -- & Flood \\
\hline Rent out crop land & 9 & -- & $\begin{array}{l}\text { Soil fertility, Flood, } \\
\text { Drought }\end{array}$ \\
\hline
\end{tabular}

To maintain productivity while facing challenges from climate change, farmers are needed to respond with effective and ambitious adaptation measures. Agricultural adaptation to climate change includes adjustments made to the agricultural system in response to current or future climate changes, which enhances resilience towards climate change (Abit et al. 2015). In our case, farmers mostly utilize changing fertilizers, seed quality, plant shaded trees and changing crop variety as the most commonly and frequently adaptation methods. However, none of the households noted improvement in agricultural yield due the application of such adaptation techniques. This could be due to the lack of farmers' inability to determine which adaptations are most effective at increasing farmers' resilience as identified by Deressa et al. (2009) in Ethopia and Abid et al. (2016) in Punjab province of Pakistan. As mentioned earlier, information sharing on climate change was mostly through village elders who had the experience of farming for a long time. This experience enabled farmers to identify the changing weather conditions over a longer period. On the other hand, farmers rarely apply that knowledge on the field to improve agricultural production, this is evidenced by considering the adaptation strategies deployed by farm household at our study area. Sampled respondents, in most cases, look for economically feasible adaptations instead of environmentally feasible. By doing so, farmers face 
situations in which they struggle to improve agricultural production. This is probably due to the ignorance towards impacts of climate change on agriculture in the region. For most of these adaptations, farmers generally followed their co-workers. Interestingly, both the experienced farmers and their followers were not sure how will those adaptations help improve agricultural yields. For instance, only 2\% of the farmers in Shabara have tried changing crop varieties compare to 33\% in Gulabad. Due to the high exposure towards floods risk, more than half of the farmers have already planted trees for protecting their land, lives, and properties. However, not many of the sampled respondents stopped cutting trees as they need it for fuelwood consumption. Similarly, not many of the households have tried diversifying farm management techniques and look for other alternative livelihoods that could help in time of hardship.

Lessons learned from this study on how farmers perceive climate change, ongoing adaptation measures, are important for crafting policies and programs aimed at promoting successful adaptation of the agricultural at the farm level. However, in the case of Pakistan, the current level of support for the agriculture sector in terms of climate change adaptation is very limited due to poor implementation of climate policy and the very low technological and financial capacity of the country in adapting to climate change (Ullah et al. 2015; Ullah et al. 2017). Hence, vulnerability to climate-related risks may be reduced if farmers effectively adapt to the changing conditions to reduce losses in crop yields. To achieve this goal, farmers will need support from multiple stakeholders such as local government agencies, agricultural extensions, researchers and from the local community.

3.8. Adaptation to climate variability across different categories of farmers based on education level and farming experience

From the results presented in previous section (3.7 and Table 4), adaptation techniques that were deployed by most of the households were further cross-checked with farmers' education level and farm experience by assuming that adaptation to climate change differs in terms of the extent to choose certain adaptation technique. The most prominent adaptation methods included in this analysis are; changing fertilizers, pesticides, seed quality, and plant shaded trees to deal with the vagaries of climate change. For this purpose, we categorized education level of farm households into three categories: illiterate farmers with no formal education; those with 1 to 5 years of schooling; farmers with more than 5 years of schooling (Figure 6). Results indicate that illiterate farmer tends to adopt less compare to those with relatively higher education level. In Gulabad, 36\% of farmers with more than five years of schooling employed changing fertilizers as an adaptation strategy for improving agricultural yields whereas interestingly $37 \%$ of the farmers having no formal education in Shabara, have focused on changing seed quality. As discussed earlier, although, farmers did try to shift from one strategy to another year by year, they always emphasized on searching for the cheapest (in economic perspective), and/or easily accessible options. For example, farmers did change seed quality, but it does not mean that they have bought a better-quality seed or heat-resistant seed that can survive in harsh environments. Instead, they looked for seed type that they have not grown in the past few years and hope that it could help improve agricultural yield. Moreover, in both villages, the fewer number of respondents, although with slight variation, tempted to adapt to changing climatic conditions by applying new and improved crop varieties despite any relevance to their education level (Figure 6). This may be due to the poor economic condition of 
locals and because of their ignorance towards the significance of heat-resistant crop varieties. Here, it is important to mention that the absence of agricultural extension workers has worsened the situation. Those officials could educate farmers on the importance of using heat-resistant crops and seeds and could provide support in accessing where to buy it as in the case study conducted by Abid et al. (2016) in Punjab province of Pakistan.

\section{0}

40

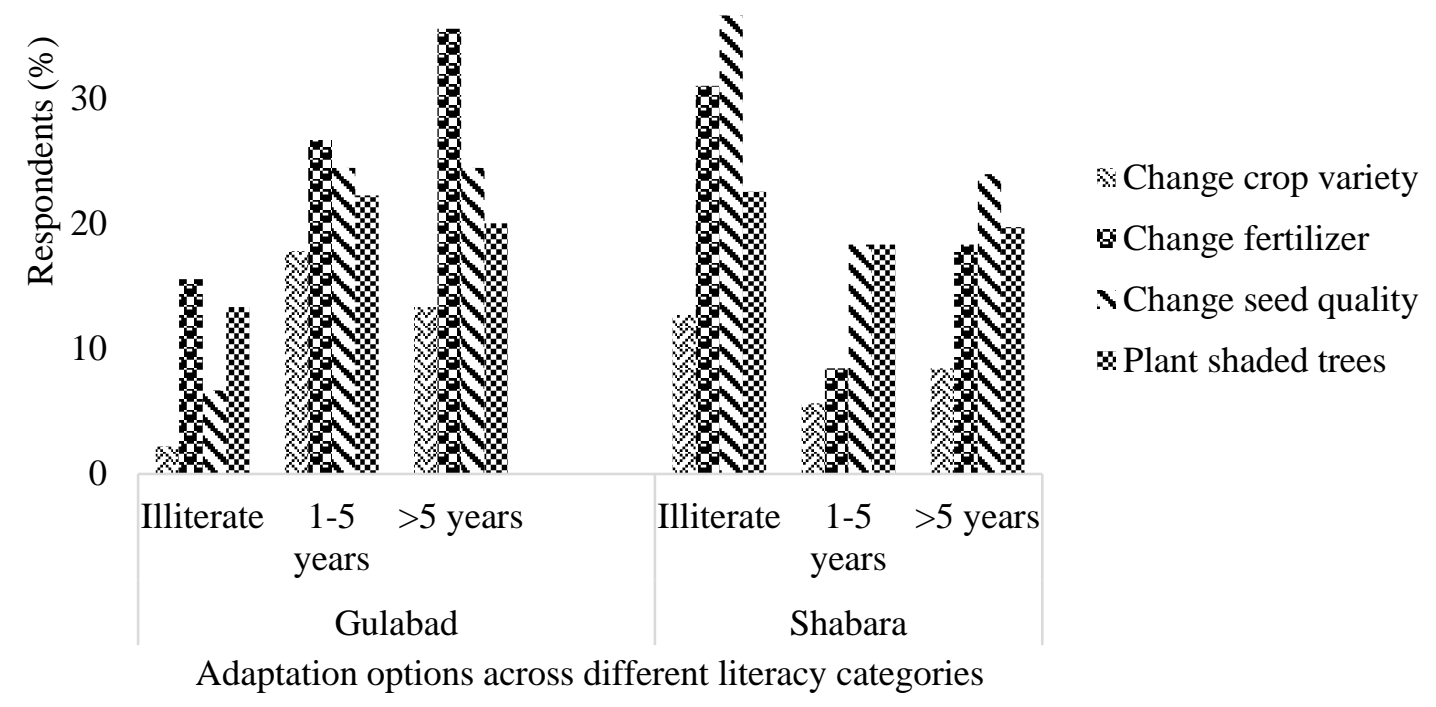

Fig. 6. Adaptation to climate change across different groups of farm household based on their education level.

The analysis of adaptation measures across various categories of farmers based on farm experience is described in Figure 7. Categories generated for farm experience were grouped into three types i.e. 1 to 10; 11 to 20 and more than 20 years of experience. Farmers who have less experience were less likely to adapt. In both villages, the fewer number of farmers with less farm experience (1 to 10 years) have tried to adapt to the changing climate. On the other hand, those with greater experience have tried all options to adapt i.e. change fertilizers, changing crop type, seed quality, and plant shaded trees. Among other socioeconomic attributes of the farm households', education and farm experience are considered as key factors in deciding how effectively farmers can or cannot adapt to climate change (Ali and Erenstein 2017). Education can help in accessing up to date information on modern agricultural techniques used widely in farming for improving productivity. Moreover, farmers with farming experience tend to be more aware of past weather and climate events and can better decide how to adapt their farming in response to extreme events (Abid et al. 2016; Adger et al. 2003). Our results are in accordance with those from Ali and Erenstein (2017); Elahi et al. (2015) and Abid et al. (2015 and 2016), who performed their studies in various parts of Pakistan. By concluding, it can be said that the higher the education level and farming experience, the higher are the chances of an individual household to adapt to the changing climatic conditions. 


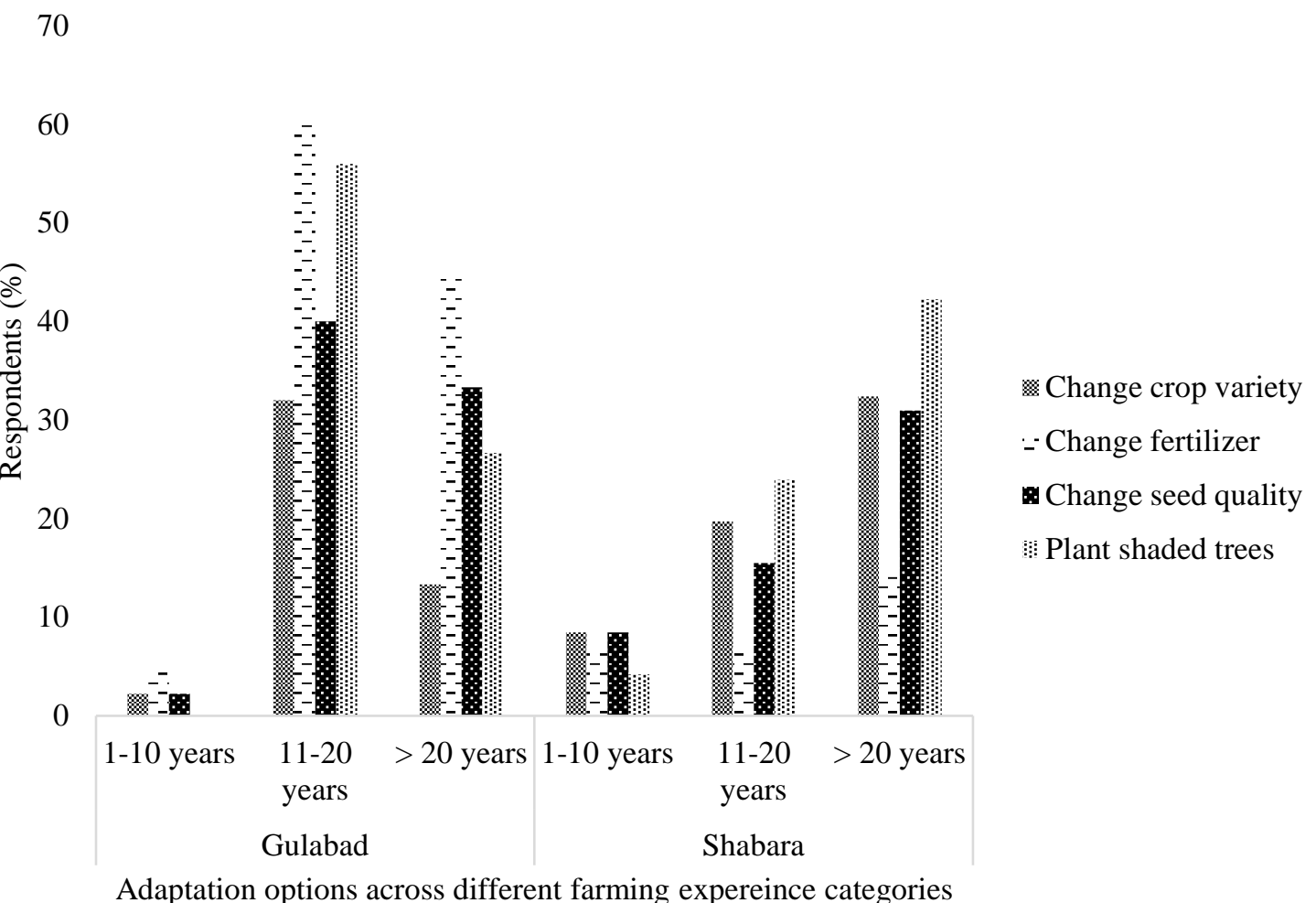

Fig. 7. Adaptation to climate change across different groups of farm household based on their farm experience.

\section{Conclusion}

This study examined farmers' perceptions of climate change associated risks, its impacts on agriculture, and adaptation the measures taken, based on household surveys conducted in the KP province of Pakistan. The surveyed farmers were asked if had observed any change in long-term weather (climate) over the years, of which the majority acknowledged changes in both short and long-term weather. Those who observed changes were further asked if they could identify and rank the key factors of climate change affecting farming. Fluctuating weather and climate variability have led to devastating consequences in the study area resulting in losses to lives, livelihoods, and other properties. These mainly include flooding, drought, heat stress and erratic rainfall patterns. By asking if they have responded to such devastating consequences, farmers reported that they mostly tend to change crop variety, change fertilizers and plant shade trees. Farmers with higher education and greater farm experience intensively used those measures in response to climatic changes. However, those adjustment measures were essentially founded on close to a home decision without having legitimate learning and data on when to utilize, how to adjust and which methodology encourages enhancing yield. Because agricultural production remains the main source of income for most rural communities in the study area, an effective adaptation of the agricultural sector to the adverse effects of climate change will be imperative to protect their lives and livelihoods. Hence, the study suggests that farmers should use more advanced farming techniques to cope with climate change and variability. Other proper adaptation techniques such as the application of heat-resistant crops, water, and soil conservation, use of better-adapted crop varieties, altering 
planting dates etc. must also be utilized to guarantee imbitious yield. This aim could not be achieved with the greater involvement of multiple stakeholders such as policymakers, extension agents, researchers, and farmers to effectively minimize impacts of climate change on agriculture in the region and to strengthen local adaptation capacities.

\section{Conflict of interest}

On behalf of all authors, the corresponding author states that there is no conflict of interest.

\section{References}

Abbass, Z. (2009). Climate change, poverty and environmental crisis in the disaster-prone areas of Pakistan. Oxfam Policy and Practice: Climate Change and Research, 5(3), 1-96.

Abid, M., Scheffran, J., Schneider, U. A., \& Ashfaq, M. (2015). Farmers' perceptions of and adaptation strategies for climate change and their determinants: The case of Punjab Province, Pakistan. Earth System Dynamics, 6(1), 225-243.

Abid, M., Schilling, J., Scheffran, J., \& Zulfiqar, F. (2016). Climate change vulnerability, adaptation and risk perceptions at farm level in Punjab, Pakistan. Science of the Total Environment, 547, 447-460.

Adger, W., N., Huq, S., Brown, K., Conway, D., \& Hulme, M. (2003). Adaptation to climate change in the developing world. Progress in Development Studies, 3, 179-195.

Ali, A. \& Erenstein, O. (2017). Assessing farmer use of climate change adaptation practices and impacts on food security and poverty in Pakistan. Climate Risk Management, https://doi.org/10.1016/j.crm.2016.12.001

Anita, W., Dominic, M., \& Neil, A. (2010). Climate change and agriculture impacts, adaptation and mitigation: Impacts, adaptation and mitigation (pp. 136.). OECD Publishing.

Arbuckle, J. G., Hobbs, J., Loy, A., Morton, L. W., Prokopy, L., \& Tyndall, J. (2014). Understanding farmer perspectives on climate change: Toward effective communication strategies for adaptation and mitigation in the corn belt. Journal of Soil Water Conservation, 69(6), 505-516.

Atta-ur-Rahman., \& Khan, A. M. (2013). Analysis of 2010 flood causes, nature and magnitude in the Khyber Pakhtunkhwa, Pakistan. Natural Hazards, 66(2), 887-904.

Chaudry, A. Z. (2017). Climate change profile of Pakistan. Asian Development Bank (ADB), Manila, Philippines. 1128. http://dx.doi.org/10.22617/TCS178761

Deressa, T. T., Hassan, R. M., Ringler, C., Alemu, T., \& Yesuf, M. (2009). Determinants of farmers' choice of adaptation methods to climate change in the Nile Basin of Ethiopia. Global Environmental Change, 19(2), 248-por, 255.

CERD-EM-DAT (Centre for Research on the Epidemiology of Disasters-Emergency Disaster Database). (2016). Available on http://www.emdat.be/natural-disasters-trends. (accessed on September 2016).

Eid, H. M., El-Marsafawy, S. M., \& Ouda, S. A. (2007). Assessing the economic impacts of climate change on agriculture in Egypt: A Ricardian Approach. Development research group, sustainable rural and urban development team: The World Bank, policy research working paper 4293. 
Ekpoh, I. J. (2010). Adaptation to the impact of climatic variations on agriculture by rural farmers in north-western Nigeria. Journal of Sustainable Development, 3(4), 194.

Elahi, E., Zhang, L., Abid, M., Altangerel, O., Bakhsh, K., Uyanga, B., Ahmed, U. I., \& Xinru, H. (2015). Impact of balance use of fertilizers on wheat efficiency in cotton wheat cropping system of Pakistan, International Journal of Agricultural Research, Innovation and Technology, (3), 1470-1474.

Farooqi, A. B., Khan, A. H., \& Mir, H. (2005). Climate change perspective in Pakistan. Pakistan Journal of Metrology, 2(3), 11-21.

Harmeling, S. (2011). Global climate risk index 2012: Who suffers most from extreme weather events? Weatherrelated loss events in 2010 and 1991 to 2010, Germanwatch e.V., Bonn, Germany.

Hoffmann, U. (2013). Section B: Agriculture - a key driver and a major victim of global warming, in: Lead article, in chapter 1, Hoffmann, (pp. 3-5). http://www.census.gov.pk/publications.php. (accessed October, 2016).

Hussain, S. S., \& Mudasser, M. (2007). Prospects for wheat production under changing climate in mountain areas of Pakistan-An econometric analysis. Agricultural Systems, 94(2), 494-501.

IPCC (Intergovernmental Panel on Climate Change). (2007). Climate change 2007: The physical science basis. Contribution of Work Group I to the Fourth Assessment Report of the Intergovernmental Panel on Climate, Cambridge University Press, United Kingdom.

Javed, S. (2016). A study on Pakistan's vulnerability to climate change, current policies and institutional set-up for dealing with it. Master's thesis, Norwegian University of Life Sciences, Norway.

Khan, M. A., Khan, J. A., Ali, Z., Ahmad, I., \& Ahmad, M. N. (2016). The challenge of climate change and policy response in Pakistan. Environment Earth Science, 75(5), 1-16.

Khan, R. A. (1994). Over view of NWFP agriculture (current Khyber Pakhtunkhwa or KPK), (Peshawar: Nespak OPCV), 1-15.

Khan, S., Shahnaz, M., Jehan, N., Rehman, S., Shah, M. T., Din, I. (2013). Drinking water quality and human health risk in Charsadda District, Pakistan. Journal of Cleaner Production, (60), 93-101.

Kurukulasuriya, P., \& Rosenthal, S. (2003). Climate change and agriculture: A review of impacts and adaptations World Bank climate change series paper no. 91. Paper prepared and published for the rural development group and environment department of the World Bank 106.

Lebel, P., Whangchai, N., Chitmanat, C., \& Promya, J. (2015). Perceptions of climate-related risks and awareness of climate change of fish cage farmers in northern Thailand. Risk Management, (17), 1-22.

Lucas, M. P., \& Pabuayon, I. M. (2011). Risk perceptions, attitudes, and influential factors of rain-fed lowland rice farmers in Ilocos Norte, Philippines. Asian Journal of Agriculture and Development, 8 (2), 61-77.

Malik, S. (2012). Case study: Exploring demographic dimensions of flood vulnerability in rural Charsadda, Pakistan. Master thesis: appendix 4, available at: https://assets.publishing.service.gov.uk/media/57a08a65ed915d3cfd000746/Indus_Floods_Research_Appe ndix_4.pdf

MoE. (Ministry of Environment). (2009). Climate change vulnerabilities in agriculture in Pakistan. Ministry of Environment, Government of Pakistan, Annual Report. 1-6. 
Porter, J. R., Xie, L., Challinor, A. J., Cochrane, K., Howden, S. M., Iqbal, M. M., Travasso, M.I., et al. (2014). Chapter 7: Food security and food production systems. (archived 5 November 2014), in IPCC AR5 WG2 A 2014, (pp. 488-489). Cambridge University Press.

Qasim, S., Khan, A. N., Shrestha, R. P., \& Qasim, M. (2015). Risk perception of the people in the flood prone Khyber Pakhtunkhwa province of Pakistan, International Journal of Disaster Risk Reduction, 14, 373-378.

Rasul, G., Mahmood, A., Sadiq, A., \& Khan, S. I. (2012). Vulnerability of the Indus Delta to climate change in Pakistan. Pakistan Journal of Metrology, 8(16).

Roncoli, C., Ingram, K., \& Kirshen, P. (2001). The costs and risks of coping with drought: Livelihood impacts and farmers responses in Burkina Faso. Climate Research, 19(2), 119-132.

Saif-ur-rehman, S. A., \& Shaukat, B. (2013). The effects of 2010 flood on educational institutions and children schooling in Khyber Pakhtunkhwa: A study of Charsadda and Swat Districts. International Journal of Environment Ecology Family and Urban Studies (IJEEFUS), 3(3), 1-12.

Salik, K. M., Ishfaq, S., Saeed, F., Noel, E., \& Syed Q. A. (2015). Pakistan: Country situation assessment. Islamabad: Sustainable Development Policy Institute Working paper.

Shakoor, U., Saboor, A., Ali, I., \& Mohsin, A. Q. (2011). Impact of climate change on agriculture: Empirical evidence from arid region. Pakistan Journal of Agricultural Research, 48(4), 327-333.

Sultana, H., \& Ali, N. (2006). Vulnerability of wheat production in different climatic zones of Pakistan under climate change scenarios using CSM-CERES-Wheat Model. In second International Young Scientists' Global Change Conference, Beijing. 7-9.

Sultana, H., Ali, N., Iqbal M. M., \& Khan, A. M. (2009). Vulnerability and adaptability of wheat production in different climatic zones of Pakistan under climate change scenarios. Climatic Change, 94(1), 123-142.

Ullah, R., Shivakoti, G. P., \& Ali, G. (2015). Factors effecting farmers’ risk attitude and risk perceptions: The case of Khyber Pakhtunkhwa, Pakistan. International Journal of Disaster Risk Reduction, (13), 151-157.

Ullah, W., Nihei, T., Nafees, M., Zaman, R., \& Ali, M. (2017). Understanding climate change vulnerability, adaptation and risk perceptions at household level in Khyber Pakhtunkhwa, Pakistan. International Journal of Climate Change Strategies and Management, 10(3), 359-378, https://doi.org/10.1108/IJCCSM-02-2017-0038

Yu, W., Yang, Y. C., Savitsky, A., Brown, C., \& Alford, D. (2013). The Indus Basin of Pakistan: The impacts of climate risks on water and agriculture. World Bank Publications. https://assets.publishing.service.gov.uk/media/57a08a65ed915d3cfd000746/Indus_Floods_Research_Appe ndix_4.pdf. 